\title{
Role of Iranian immigrants in Iran - Russia trade development
}

\author{
Mehdi Afzali \\ Peoples' Friendship University of Russia (RUDN University) \\ 6 Miklukho-Maklaya St., Moscow, 117198, Russian Federation
}

\begin{abstract}
Migration and international trade are two important dimensions of globalization. Migration plays an important role in development of countries. Immigrants send their remittances, ideas, innovation and investments to their home countries. Migrants can influence on countries' trade, they are able to decrease the transactional costs for companies willing to trade. In this article has been tried to study the case of Iranian immigrants in Russia. We can see that Iranians have migrated mostly to developed countries such as USA, Europe, Australia, Canada and part of them have migrated to the Persian Gulf countries. And of course many of these immigrants have high levels of economic, human, social, and cultural potential, which can be used for social and economic development of the country. Iranians have migrated to two kinds of countries. First, those who are developed and second those with high income which have the potential of trade with Iran. When we look at these two groups they either migrated to American and European countries, which this group has a high educated and human capital background or they migrated to neighbor Persian Gulf countries that they have mostly strong economic backgrounds which increased the chance of trade. In this article Iranian businessmen have been interviewed and they have explained their roles in trade, and if they had any advantages in comparison with those in the home country.
\end{abstract}

Keywords: migration, emigration, immigration, international trade, trade

\section{Introduction}

Migration and international trade are two important factors of globalization. Governments of many countries have been trying to open their borders to trade but they have been very conservative to open their borders to immigrants and they put strongly restricted immigration policies. But it is very important to know if governments could create a positive connection between immigration and their international trade. Moreover, it is interesting to know if it is a connection, how they could encourage the required immigrants. Volume of services traded have been increased over the period of 1980 to 2011 and outpaced growth in goods trade, and global trade grew on average by $7.3 \%$ annually while services trade grew by $8.2 \%$ per year. In this period immigration in many developed countries started to increase. But unfortunately, the link between immigrants and trade has not been fully explored.

However, migration plays an important role in development of countries. Immigrants send their remittances, ideas, innovation and investments to their home countries. Today $3 \%$ of the world's population live or work outside of their home country around 175 
million people ${ }^{1}$, therefore it has social and economic effects on both home and host countries. More than 100 million labor migrants have made challenges for both home and host countries (Heilmann, 2006). According to the Global Development Finance ${ }^{2}$, remittances have very huge impact on developing countries of Asia, Africa, Latin America and Middle East, which in some cases is the second main source of investment in those developing countries. International Remittances are now officially 93 billion dollars per year (Ratha, 2004), therefore migration plays an important role in the economic development and immigrants are important parts of a country's economy, and because of the relations caused by the immigrants, it helps the countries with the process of integration into the global economy and their investment, and savings back in their country help the economic growth and expand the relation between the diasporas and home countries. It is showed that most of the international migration takes place from developing countries towards the developed ones and families and workers migrate to developed and industrialized countries of Western Europe or America, which is called brain drain, absorption of specialists to industrialized countries (Moshfegh, 2013).

In case of Iran although Iran has a considerable number of international immigrants but unfortunately there is no sufficient data and statistics and there is no enough accurate information. But we can see that Iranians have migrated mostly to developed countries such as USA, Europe, Australia, Canada and part of them migrated to the Persian Gulf countries. And of course many of these immigrants have high levels of economic, human, social, and cultural potential which can be used for social and economic development of the country.

\section{Literature review}

Table 1 shows the estimation number of Iranian emigrants in the middle of 2018 which the top 10 destinations of migration are listed, as you see, the flow of migration is towards developed countries that shows the great potential of Iranian migrants in economic development of the country and how they could influence the trade.

Table 1

Emigrants' population by country of origin Iran and destination, 2018 estimates

\begin{tabular}{|l|l||l|l|}
\hline \multicolumn{1}{|c|}{ Emigrants to } & \multicolumn{1}{c|}{ Number } & \multicolumn{1}{c|}{ Emigrants to } & \multicolumn{1}{c|}{ Number } \\
\hline UAE & 412.400 last estimate 2013 & Sweden & 69.067 \\
\hline The United States & 386.073 & Australia & 55.650 \\
\hline Canada & 140.318 & Kuwait & 46.419 \\
\hline Germany & 119.000 & Netherlands & 29.670 \\
\hline United Kingdom & 77.000 & France & 23.134 \\
\hline
\end{tabular}

Source: International Organization for Migration. https://www.iom.int/

1 United Nations, Department of Economic and Social Affairs, Population Division (2002). International Migration Report 2002. New York: United Nations.

2 World Bank (2004). Global development finance 2004: harnessing cyclical gains for development. URL: http://documents.worldbank.org/curated/en/858571468137998042/pdf/288100PAPER0V12 GDF0200401TYPE0GDF1.pdf (accessed: 10.10.18). 
It is shown that when remittances are sent to developing countries are much more than foreign aid, and this fact actually increased the interest of the relationship between immigration and development among researchers and policy makers (DeWind, Holdaway, 2005). And therefore remittances are considered as a major source of external finance for developing countries (Acosta, 2008) and increases the economic growth. So this relation between migrants and the countries finally causes flows of money, knowledge, innovation, ideas and investment. For example you can thee Iranian case in the following table.

Table 2

Remittances (years are approximate for some indicators/countries)

\begin{tabular}{|l|c|c|c|}
\hline & 2000 & 2010 & 2012 \\
\hline Inflows (millions of US dollars) & 536 & 1181 & 1376 \\
\hline Outflows (millions of US dollars) & $\ldots$ & $\ldots$ & $\ldots$ \\
\hline Inflows as a share of GDP \% & 0.5 & 0.3 & 0.3 \\
\hline
\end{tabular}

Source: UNICEF.

According to Migration Policy Institute "Iran has produced and hosted abundant flows of emigration and immigration, a steady coming and going mainly driven by key political events". Iran in 2012: received international remittances as 1.3 billion dollars or $0.3 \%$ of its GDP that as a receiving country ranked 74th and in terms of GDP ranked 134 th in the world. Iran has been forced to be abounded from the rest of the world since Islamic revolution in the country in 1979. But it has extreme flows of emigration and immigration mostly derived by social and political reasons. Emigration movements are also part of Iranian history.

So the remittances could influence on the purchasing power or even the production power of families or communities' members who received it and finally could affect the trade as well, it could reduce the poverty and increase the consumption which expands the money supply in the country through the households' spending (Gupta et al., 2009). But it is very important to be sure, where these remittances are invested, which for every country is different, some they invest in education and health and some may invest in agricultural industry. But in case of Iran these remittances can be used to either empower the exporting industries by helping them to better their productions, or increase their purchasing power of people to buy the imported products. And from different studies we understand that remittances could help the economic growth, and it could have positive impact on consumption, savings and investments. But how this could be related to trade? There are estimates that $10 \%$ increase in the global immigrants might cause global trade to increase by $29 \$$ billion (Genc, 2013).

When we look at table 1, we can see that Iranians have migrated to two kinds of countries. First, those who are developed and second those with high income which have the potential of trade with Iran. When we look at these two groups they either migrated to American and European countries, which this group has a high educated and human capital background or they migrated to neighbor Persian Gulf countries that they have mostly strong economic backgrounds which increased the chance of trade.

But how these migrants can help the trade. Trade is a very risky, difficult and time consuming business. It is very difficult for both suppliers and buyers to find each other 
in another country, because it needs time, money and knowledge, there are many frauds in trade and if people do not know exactly the process they will get the pain, and that is why trade has high transactional costs. The real problem is not actually on the shoulders of big companies but the small and medium sized enterprises. Because they usually need to deal with partners abroad all by their own, they have independent decision making, transaction costs and responsibilities and therefore they should assume more risks (Girma, Yu, 2007; Istrate et al., 2010). And therefore sometimes these SMEs cannot be successful in the foreign market as it needed to be, it has few reasons, which are lack of information about the foreign market, insufficient language skills and etc.

The weakness mentioned above has exception among the SMEs who have more immigrants and ethnic minorities. And SMEs with more ethnical background are more successful than those without. It is reported that minority owned exporting firms were more successful in international trade, and they were also larger in terms of receipt size and employment ${ }^{1}$. It has been showed that there is relation between immigration and international trade, when the immigrants arrived, trade between that country and country of origin has increased, moreover it is caused by the information that immigrants have from both home and host countries' customs and business practices, their language, formal and informal connections and structures, so they could reduce their transaction costs (White, 2010).

\section{Methodology}

So based on information explained above this article is designed to find out if the Iranian immigrants and entrepreneurs in Russia could make any differences in business and trade process between the countries. 10 Iranian immigrants' businessmen were invited to the interview which all of them were male. Age range rate from $28-60$ years and they have been living in Russia from 5-23 years busy with merchandising wide range of products but mostly agricultural products. They were asked questions about their living and working situation in Russia, how they could make any social and economic relations with Russian people and even with people back in Iran. They were asked if they have ever done any business or trade specifically with Iran. Moreover they were asked to explain how they could do so. The interview was in Persian based on their preferences and we recorded the answers on paper. We have used their words to analyze and explain the situation specifically in Russia. All these businessmen were living and working in Moscow, and we used the snowball method, one businessman was known and we progressed from him to find new businessmen to reach 10 people (Salganik, Heckathorn, 2004). We have direct translations of what they told and we tried to analyze them straightly.

\section{Results}

As a result out of 10 immigrants 8 of them are currently doing business with Iran, 2 of them have worked and now again looking for to do so. What it was extracted, showed that

1 US Census Bureau (2007). Ownership Characteristics of Classifiable U.S. Exporting Firms: 2007. Survey of Business Owners Special Report. URL: https://www2.census.gov/econ/sbo/07/sbo_export_ report.pdf (accessed: 10.10.18). 
they all agreed that they are enjoying the economic, social and even the cultural position which they have, they mentioned that specially because of the insufficient Russian language knowledge of business partners in Iran they are well off. And they showed that their key advantage was the knowledge of Russian language.

"When I came to Moscow I did not know the language I studied it a lot, and now it is my time to use my instrument, not many Iranians know Russian language well, and not many Russians speak Persian or English, therefore, I am having fun here"

Moreover they explained that since the cultural differences in life and business is touchable between the two countries, finding the information is very difficult, they feel that they are sufficiently integrated with the new society, they understand the process of business in Russia and they know how to cope this system, they talked about the corruption as if it is inside the business culture, which they considered this as useful information to know to operate a business.

"About business I can tell you that, here in Russia is difficult to work of course but it is easy as well, you can do everything with money, if you know how to do business then you always can do it. Of course I pay my taxes, but I am not afraid of problems I face because I know I can find solutions for them with money, and this is what our partners in Iran do not know, so someone could help them"

One very important factor that 3 of them argued is the intra-ethnical relations they had with people from Tajikistan, Azerbaijan, Armenia and such countries which helped them not only expand their business in Russia but also they could consider those countries as their target market and it was mentioned as an favorable option and one of the advantages of trade in Russia.

"Working in Russia is not just working with Moscow or Saint Petersburg, when we came here we planned to target the Russian market, but nowadays maybe I can tell that I have more customers from Tajikistan and Azerbaijan than Russians, and I am straightly sending my products to their countries, from my base office in Moscow"

"When you work in Russia you are working with the region and you can include CIS countries in your business process”.

"Moscow is not capital of Russia for business, it is the capital of the region"

Moreover, they explained that working in the Iranian diaspora in Russia has helped them to solve many problems related to business, transportation, banking and finance, therefore, they seek to find more Iranian businessmen.

"When I moved to Moscow I could not even order a food for myself and I did not even know English language, I found Iranian friends, who were here long before me, and they helped me to cope with many of business problems, I could ask their help anytime I wanted, and they supported me with all their power and I could use their connections"

In addition, we asked them if they have ever tried to convince others to start a business in Russia, what we received from the answer is very important, they mentioned that of course they have tried to convince people to start a business in Russia but people are mostly afraid of doing so. They consider Russia as a high risk country for business, fear of corruption, mafia, bureaucracy, contractual violations and language stopped them from doing so. They explained that they have been helping people to open companies in Russia, and they are earning money with this method besides their main business. And they mentioned that their fear is true and they must be very cautious about it. 
"Of course I have convinced people to work in Russia. Russia has huge market for Iranian products. I have opened more than 150 companies for Iranians so far. But they do not use it well. They don't know what to do. They stuck here, they don't know the process"

"They are so afraid of Russia, is difficult to convince them, and I understand them, they are right"

"I have helped many Iranians, but they are afraid, what can I do"

They are still worried about the social network among the diaspora, they mentioned if something could be done to collect diaspora at one place as an association it could help trade, business and their life more efficiently. Sometimes, fairs and exhibitions are held by the embassy to promote the Iranian products and that they all could be gathered in one place, but they consider it not enough and useless. Two of them suggested that embassy could make a yellow book of Iranian companies and businessmen in Russia that it was easier to find each other.

"We could have at least an organized association for our Diasporas"

"Embassy could make a list of Iranian companies businesses in Russia, they could do many things, but don't"

"We need something like a yellow book, we could have Iranian companies list to find each other. How can I find out who does what? Of course I will to work with them, embassy exhibition, is good for nothing, it is just wasting the money, no advertisement no good announcement, nothing"

Furthermore, we asked them what disadvantages they could have as an immigrants businessmen in Russia. Besides what they mentioned as corruption, mafia and others explained above, they added few more important negative factors from their experience. First, "sanctions", they mentioned that because the main side of their business is Iran, because of the sanctions on the country they are worse off, they cannot easily change money in the exchange offices, banking system and swift is not working, and they face transportation and custom problems in Russia. They mentioned that they are even worried of the sanctions, which West is putting against Russia that is devaluating ruble by 2.5 times from five years ago. Second is the business and trade discrimination, especially in Russian custom borders, against their competitor countries such as Turkey and Azerbaijan. The other discrimination happens during the contract step or finding the customers when politically or racially are discriminated unless they knew someone that could recommend them.

\section{Conclusion}

Of course immigrants as businessmen or trader could be more successful in export and import generally in independent businesses but many factors still influence their progress. These factors start from the immigrant himself as an individual to the political, social and economic factors which influence on him and his business as a whole. Generally, it is highly related to immigrant himself, what knowledge he has, what languages he talks, how he could psychologically be adapted and integrated in the new society. It is very important how he can analyze the market as it is, predict the upcoming opportunities and threats and make the best decisions. Moreover, it is very important to know how to 
make connection with other diaspora to use their experiences and connections and to use the social networks.

From the information obtained from 10 Iranian immigrants in Russia we understand that they mostly focused on Iran as the main side of their trade, could be dangerous for them in the current situation and it is highly recommended that they start to think more globally than regionally. And it is necessary to as fast as possible with growing number of immigration of Iranians to Russia provide an association where they could meet and help each other. Although Iranian immigrants in Russia are making partnerships with countries such as Tajikistan and Azerbaijan it is still necessary to be more cautious about it and increase their knowledge about those countries. Contracts and dealing is not a shaking hand process, is not related to discrimination. It is the explanation of business.

As conclusion we may not be able to surely explain if the immigration could eliminate the transaction costs, but for sure it helps to have faster, easier and cheaper process. Besides, it is very important to have the links among the Diasporas and people in the homeland. Future researches will help us to find the best answers and decisions.

(C) Afzali M., 2018

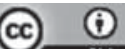

This work is licensed under a Creative Commons Attribution 4.0 International License

\section{References}

Acosta P., Caldero'n C., Fajnzylber P, Lopez H. (2008). What is the Impact of International Remittances on Poverty and Inequality in Latin America? World Development. Vol. 36. No. 1. Pp. 89-114.

DeWind J., Holdaway J. (2005). Internal and international migration in economic development. Paper presented to the Fourth coordination meeting on international migration, Population division of the UN, New York, 26-27 October.

Genc M., Gheasi M., Poot J., Nijkamp P. (2013). The impact of immigration on international trade: a meta-analysis. In: Nijkamp P., Poot J., Sahin M. (eds). Migration Impact Assessment: New Horizons. Cheltenham, UK: Edward Elgar. Pp. 301-337.

Girma S., Yu Z. (2007). The link between immigration and trade: evidence from the U.K. Review of World Economics. Vol. 138. No. 1. Pp. 115-130.

Gupta S., Pattillo C.A., Wagh S. (2009). Effect of Remittances on Poverty and Financial Development in Sub-Saharan Africa. World Development. Vol. 37. No. 1. Pp. 104-115.

Heilmann C. (2006). Remittances and the migration - development nexus - Challenges for the sustainable governance of migration. Ecological Economics. Vol. 59. No. 2. Pp. 231-236.

Istrate E., Rothwell J., Katz B. (2010). Export Nation: How U.S. Metros Lead National Export Growth and Boost Competitiveness. Metropolitan Policy Program of the Brookings Institution.

Moshfegh M. (2013). Evaluation of international migration statistics in selected countries in Asia and the Pacific. National Population Studies \& Comprehensive Management Institute, Iran.

Ratha D. (2004). Appendix A: Enhancing the developmental effect of workers' remittances to developing countries. Global development finance. Washington, DC: World Bank. Pp. 169-173.

Salganik J.M., Heckathorn D.D. (2004). Sampling and estimation in hidden populations using respondent-driven sampling. Sociological Methodology. Vol. 34. No. 1. Pp. 193-239.

White R. (2010) Migration and International Trade: The US Experience Since 1945. Cheltenham, UK. 
Article history:

Received: 28 September 2018

Revised: 29 October 2018

Accepted: 26 November 2018

\title{
For citation:
}

Afzali M. (2018). Role of Iranian immigrants in Iran - Russia trade development. RUDN Journal of Economics, 26(4), 697-705. DOI: 10.22363/2313-2329-2018-26-4-697-705

\section{Bio Note:}

Mehdi Afzali, Ph.D. Student, International Economic Relations Department, Faculty of Economics, Peoples' Friendship University of Russia (RUDN University). Contact information: e-mail: mehdiafzali1991@gmail.com

\section{Роль иранских иммигрантов в развитии торговли между Ираном и Россией}

\author{
М. Афзали \\ Российский университет дружбы народов \\ Российская Федерация, 117198, Москва, ул. Миклухо-Маклая, 6
}

\begin{abstract}
Миграция и международная торговля - два важнейших аспекта глобализации. Миграция играет важную роль в развитии стран. Иммигранты отправляют в свои родные страны денежные переводы, идеи, инновации и инвестиции. Мигранты могут влиять на торговлю между странами, снижать транзакционные издержки компаний, желающих торговать. В этой статье предпринята попытка изучить основные стратегии бизнеса иранских иммигрантов в России. Проведенное исследование показало, что иранцы мигрируют, как правило, в экономически развитые страны, такие как США, ЕС, Австралия, Канада; часть из них мигрировала в страны Персидского залива. И, конечно же, многие из этих иммигрантов имеют высокий уровень экономического, человеческого, социального и культурного потенциала, который может быть использован для социально-экономического развития страны. Основные миграционные потоки из Ирана направлены в две группы стран. Во-первых, страны с развитой экономикой (Северная Америка и Европа), куда мигрируют иранцы, имеющие высокий уровень образования и человеческого потенциала. Вторая группа - развивающиеся страны (главным образом страны Персидского залива), где сейчас сложились благоприятные экономические условия для наращивания торгового оборота с Ираном. В статье приведены результаты опроса иранских бизнесменов, рассказавших о своей роли в торговле и о том, имеют ли они какие-либо преимущества по сравнению с условиями, в которых они работали на родине.
\end{abstract}

Ключевые слова: миграция, эмиграция, иммиграция, международная торговля, торговля

\section{История статьи:}

Дата поступления в редакцию: 28 сентября 2018

Дата проверки: 29 октября 2018

Дата принятия к печати: 26 ноября 2018 


\section{Для цитирования:}

Афзали М. Role of Iranian immigrants in Iran - Russia trade development (Роль иранских иммигрантов в развитии торговли между Ираном и Россией) // Вестник Российского университета дружбы народов. Серия: Экономика. 2018. Т. 26. № 4. C. 697-705. DOI: 10.22363/2313-2329-2018-26-4-697-705

\section{Сведения об авторе:}

Афзали Мехди, аспирант кафедры международных экономических отношений экономического факультета Российского университета дружбы народов. Контактная информация: e-mail: mehdiafzali1991@gmail.com 